\title{
MARKET POWER OF INDONESIAN BANKING
}

\author{
Andi Fahmi Lubis ${ }^{1}$
}

\begin{abstract}
This study aimed to estimate the degree of market power exercised by commercial banks in the credit market in Indonesia. The model used to answer this study's objective was the Bresnahan-Lau oligopoly model that uses structural equations to estimate the degree of market power. This model uses a very different approach than Structure-Conduct-Performance (SCP) paradigm commonly used in market power studies. Without using actual cost data and accounting profit, the Bresnahan-Lau model was able to estimate directly the degree of market power from the structural equations. The main result of this study showed that the degree of market power exercised by commercial banks in the credit market is relatively low; in other words, the degree of competition in the credit market in Indonesia is quite high.
\end{abstract}

Keywords: market power, oligopoly, Bresnahan-Lau, structure, performance, conduct, SCP. JEL Classification : L13, G21

1 The author is a lecturer at Master of Planning and Public Policy of Economic and Business Faculty, University of Indonesia; andi.fahmi@ui.ac.id. Points of view and conclusions in this paper are solely of the author and do not necessarily represent any other institution. The author is deeply thankful to the anonymous referee for the comment and suggestions on this paper. 


\section{INTRODUCTION}

Market power is a measure of performance that shows how much a firm can increase the price above the marginal cost (Church and Ware, 2000). Associated with the market structure, a firm in perfectly competitive market does not have any market power, while a firm in a monopoly market has the strongest market power. Thus it can be concluded that the more competitive a market is, the lower the market power of a firm; conversely, the more uncompetitive a market is, the higher the market power of a firm.

Analysis of the level of competition in a market using market power measurement has been a major focus in industrial economic studies, including assessments of the level of competition in the banking industry. As an industry that serves as intermediary institutions between those who have excess funds (surplus spending units) and those who need the funds, the banks play a very vital role in supporting the process of development. If distortion occurs in the banking industry, which generates an inefficient performance, then the intermediary process between those who need funds and fund owners will have some barriers. The existence of these barriers would hinder the funds to finance projects for development.

Considering the importance of the banking function for the development of economy, the government will try to keep the banking industry performing its intermediaries function. Various government policies will be taken to increase efficiency in the banking industry. Indonesia's banking industry had experienced significant developments since the implementation of the deregulation package in 1983, which Cole and Slade (1996) called the phase of Reformation in 1983, followed by the phase of free-entry in 1988, famously known as PAKTO 88. The impact of the deregulation was the increase of banking intermediaries function reflected by the increase of the collected third party funds and the distributed loan. The deregulation was surely believed to increase the efficiency of banking industry reflected by the decrease of concentration level in banking industry.

The decrease of concentration level in a market will give a positive impact on market efficiency according to Structure-Conduct-Performance (SCP) approach, in which the performance of a market depends on its structure. The more concentrated a market, the greater the ability of a firm to increase the price above the marginal cost, reflecting a higher market power. This higher market power indicates lower competition level.

The competition level based on the concentration ratio is the main hypothesis construction for the studies using SCP approaches. The concentration level of Indonesian banking industry declined after deregulation in 1983 and 1988, but after this period it tended to be stable at concentrations level of CR4 by 40-50's and CR8 by'50-60's. Table 1 shows that the concentration level of banking industry in Indonesia is still at the middle level, and has not reached competitive levels. 
Analysis of market power based on the SCP approach that uses structure as an indication of the competition level in the market raises many criticisms. Among them is the endogeneity problem between the structure and the performance, where the SCP approach assumes the existence of a one-directional relationship between structure and performance; thereby asserting market performance can be indicated from the existing market structure. Another criticism is associated with the use of accounting profit or price cost margin (PCM) as a proxy of the difference between price and marginal cost. The weakness of SCP approach raised a new approach that tries to analyze the level of competition in the market that was not based on the structure of the market, but based on the behavior of existing firms in the market. New Industrial Economics (NIE) approach estimates the size of market power in a market, which is then used as an indicator of the competition level. One of the estimation models in this new approach is the oligopoly model developed by Bresnahan (1982) and Lau (1982).

\begin{tabular}{|c|c|c|c|c|c|}
\hline \multicolumn{6}{|c|}{$\begin{array}{l}\text { Table } 1 . \\
\text { Bank's Rating during the Loan Period of } 2000 \text { and } 2005\end{array}$} \\
\hline $\begin{array}{l}\text { Year } \\
2000\end{array}$ & Bank's Name & $\begin{array}{c}\text { Loan } \\
\text { Share } \\
(\%)\end{array}$ & $\begin{array}{l}\text { Year } \\
2005\end{array}$ & Bank's Name & $\begin{array}{c}\text { Loan } \\
\text { Share } \\
(\%)\end{array}$ \\
\hline 1 & Bank Mandiri & 14.95 & 1 & Bank Mandiri & 15.83 \\
\hline 2 & Bank Negara Indonesia & 10.98 & 2 & Bank Rakyat Indonesia & 10.84 \\
\hline 3 & Bank Rakyat Indonesia & 9.42 & 3 & Bank Negara Indonesia & 10.08 \\
\hline 4 & Ban Int'I Indonesia & 6.61 & 4 & Bank Central Asia & 7.13 \\
\hline 5 & Citibank N. A. & 4.47 & 5 & Bank Danamon & 5.20 \\
\hline 6 & HSBC & 2.91 & 6 & Bank Niaga & 3.84 \\
\hline 7 & Bank Tabungan Negara & 2.71 & 7 & Bank Permata & 2.77 \\
\hline \multirow[t]{3}{*}{8} & Bank Central Asia & 2.68 & 8 & Bank Int'I Indonesia & 2.47 \\
\hline & CR4 & 41.96 & & CR4 & 43.88 \\
\hline & CR8 & 54.73 & & CR8 & 58.16 \\
\hline
\end{tabular}

The main goal of this paper is to investigate the limit of Indonesian banking in setting the price. The power of firms to influence the price in a market shows the strength of their exercising market power and the existing competition level in the market. Considering the market structure is concentrated on few banks, we predict the competition level within Indonesian banking industry is relatively low, which also indicates a high market power. Joint hypothesis on competition and market power of the loan market in Indonesian banking industry will be measured and tested using Bresnahan-Lau (BL) oligopoly model framework.

The second part of this paper examines the theory and the derivation of the empirical model to estimate. The third part will discuss the methodology, while the fourth part will discuss 
the estimation result and its analysis. The conclusion and policy implication will be presented in the last part of the paper.

\section{THEORY}

Measurement of market power or the level of competition of an industry can be divided into two main approaches. The first is the traditional SCP approach, based on the use of accounting data relating to the profit and cost to measure the market power. The second approach emerging lately is the New Industrial Economics (NIE) or the New Empirical Industrial Organization (NEIO) that reduces or even eliminates the use of accounting data to measure market power. NIE approach uses a structural framework for the relationship of demand and supply to estimate market power. The approach is based on the premise that a firm in perfectly competitive market, which is the price takers, and a firm in an imperfect market, which has market power, will have different reactions on exogenous changes in demand and supply (Church and Ware, 2000).

As a reconciled mainstream (between traditional SCP mainstream and Chicago), the New Industrial Economics did not achieve its popularity by attacking the other, therefore we cannot easily determine a clear boundary line to distinguish it from previous mainstream. However, we can at least determine the specific characteristics that put it as 'new' mainstream (Lubis, 1997).

There are several characteristic. The first includes the game theory as its tool of analysis. The most obvious difference between 'traditional' and 'new' industrial economies is the explicit presentation of the game theory on the problem being examined. On traditional industrial economy, the causality flow was started from the structure to behavior, then to performance. For example, a profit over 'normal' (performance) in industry will be associated with collusive behavior that occurs due to the high concentration (structure), which is possible with the existence of barriers to entry.

With the inclusion of the game theory into the industrial economy, the flow of causalityeffect was not only one direction, but it can even flow to all directions. The correlation is not only from the structure to behavior then performance, but to the set of all possible permutations of the structure, behavior, and performance (Norman and La Manna, 1992). In the new industrial economy, the number of firms operating in the market (structure) is determined endogenously, and depends on the type of game chosen by the firm, in terms of the variable options (price, output, etc.), the timing of decision, number of games played, etc.. All factors within in the structure, behavior and performance became elements that were determined simultaneously, and were influenced by fundamental factors such as technology (or technological opportunities), demand conditions, and the degree of symmetrical acquired information. Factors such as the barriers to entry or firm-specific advantage now become the decision variables that are determined endogenously by the strategic decisions of firms. 
The second important characteristic of the NIE is its higher concern on the role of behavior (conduct) in the form of appreciation for the strategic dimension of corporate decisions. The firm does not react and adapt only towards external conditions, but also tries to make the economic environment where he belongs, give some advantages to him, considering his competitors will also do the same (Norman and La Manna, 1992).

In any policy formulation, a firm engaged in imperfectly competitive market (particularly oligopoly) should consider the impact of his policy implementation to its competitors. The change of price or output determined by a firm does not only affect sales and profits, but can also affect its competitors' sales and profit, vice versa. Every oligopolist realizes this. Depending on the completeness and the speed of information obtained, any policy changes of a firm will quickly be responded and anticipated by other firms.

From the above discussion we conclude there is interdependent characteristic among firms operating in an oligopoly market. The existence of this interdependent characteristic makes oligopolist stay in a situation where optimal decision depends on decisions taken by the other firms. Thus, in taking the best decision, a firm must be able to make the best guess possibility on the reaction of its competitors, or alternatively, its decisions should be at least difficult to be predicted by his competitors (Layard and Walters, 1978).

The use of oligopoly is the strong characteristic of NIE. Although the oligopoly theory was generally derived from the theories within the Chicago mainstream, it was the NIE approach that started to use it in empirical studies. Since NIE 'fixed' the empirical study of previous mainstreams, then the NIEW is often referred as the New Empirical Industrial Organization (NEIO).

The weaknesses of the traditional SCP approach in the empirical analysis raised a new approach that tried to decrease the use of accounting data. Market power level that belongs to a firm was obtained from the estimation to structural models that described the relationship between demand and supply curves². Timothy F. Bresnahan (1982) and Lawrence J. Lau (1982) were the first economists who put forward this approach based on the oligopoly model framework.

Model used to estimate market power in Indonesia's banking industry is BL oligopoly model using structural equation consisting of demand function and price function or supply (supply relation). Given profit function that belongs to a firm:

$$
\Pi=P q-C(q, W)-F
$$

2 Beside using structural model of supply and demand, market power estimation can be also conducted by using static comparison method, which is called as reduced-form approach. Panzar and Rose (1987) used derived revenue function of the firm (firm's reduced-form revenue function) to indicate firm's behavior. 
where $\mathrm{q}$ is output, $\mathrm{P}$ is price, $\mathrm{C}$ is variable cost, $\mathrm{W}$ is exogenous variables that affects the marginal cost or supply, and $\mathrm{F}$ is fixed costs.

While the market demand function faced by the firm is:

$$
P=f(Q, Z)=f\left(q_{1}+q_{2}+\ldots+q_{n}, Z\right)
$$

where $\mathrm{Z}$ is exogenous variable that affects demand. By including the demand function (2) into the profit function (1), then it will be:

$$
\Pi=f(Q, Z) q-C(q, W)-F
$$

By looking for the first derivation of profit function (3) to the change of $\mathrm{q}$, then function will be:

$$
\frac{d \Pi}{d q}=P+f^{\prime}(Q, Z) \frac{d Q}{d q} q-C^{\prime}(q, W)=0
$$

Then by assuming the condition is the average of all firms, then:

$$
P+f^{\prime}(Q, Z) \frac{d Q}{d q} \frac{1}{n} Q-\sum C^{\prime}(q, W) \frac{1}{n}=0
$$

and, if $\quad \lambda=\frac{d Q}{d q} \frac{1}{n}$ then equation (5) can be rewritten as:

$$
P=-\lambda f^{\prime}(Q, Z) Q+\sum C^{\prime}(q, W) \frac{1}{n}
$$

where the first derivation of the demand function $f^{\prime}(Q, Z)$ denotes marginal revenue and the first derivation of cost function $C^{\prime}(q, W)$ is the marginal cost. Recall equation $\lambda$ :

$$
\lambda=\left(\frac{d Q}{d q}\right) \frac{1}{n}=\left(\frac{d q+d \sum q_{\text {rest }}}{d q}\right) \frac{1}{n}
$$

where the $\left(\frac{d q+d \sum q_{\text {rest }}}{d q}\right)$ shows conjectural variation of the firm. Conjectural variation can be defined as a change in the overall output of other firms (the rest) that are anticipated by one firm as the result of changes in the firm's output (Bikker, 2003). 
Referring to the equation (6) we can draw conclusions related to the firm's ability to play at market prices.

1. For firms that are in a perfectly competitive market, because they are price takers, then change in a firm's output would not affect the overall output. It shows that $\lambda=0$, so that equation (6) will be:

$$
P=\sum C^{\prime}(q, W) \frac{1}{n} \quad \text { or } P=M C
$$

2. If firms form perfect collusion in the market then the increase in output of a firm would be followed by the increase in firm's output,

$$
\lambda=\left(\frac{d q+d \sum q_{\text {rest }}}{d q}\right) \frac{1}{n}=\left(1+\frac{(Q-q)}{q}\right) \frac{1}{n}=\frac{Q}{q} \frac{1}{n}=\frac{Q}{q n}=1
$$

so we got $\lambda=1$

3. If firms compete in Cournot framework, changes in the overall output would be only from one firm's output change, without any' retaliation from the rest of the firms.

$$
d \sum q_{\text {rest }}=0 \quad \text { so that } \quad \lambda=\frac{1}{n}
$$

Thus between perfect competition and perfect collusion, the value of $\lambda$ will range from 0 to 1 , which means it can be used as an indicator to show the market power level or the competition level that exists in the market. The empirical study of market power estimation to figure out the competition rate in the market can be conducted by estimating the variable $\lambda$. Therefore, to answer the purpose of the research, this study will estimate the market power of the Indonesian banking industry by estimating the value of $\lambda$ obtained from the BresnahanLau (BL) oligopoly model.

As mentioned above, the BL oligopoly model is a structural model consisting of demand and supply function. The BL oligopoly model formulation was conducted by customizing the previous demand function (2) and the price function (6). By using the inverse of demand function (2):

$$
Q=f(P, Z, \alpha)+\varepsilon
$$

and with a little adjustment in the price function (6) which is a supply curve function, then we get: 


$$
P=-\lambda f(Q, Z, \alpha)+C(Q, W, \beta)+\eta
$$

Both functions (7) and (8) above can be solved by using a two-stage least squares (2SLS) with the price $P$ and the output $q$ as a endogenous variable. The value of $\lambda$ that was obtained from the estimation of the above structural model can be used to show the strength of market power or the competition level in the market.

The demand function specification required to estimate the market power is found by determining the exogenous variables (Z), which does not only shift the parallel demand curve, but can also change the slope degree of demand curve (Bresnahan, 1982) ${ }^{3}$. It can be conducted by inserting an instrumental variable which is the multiplication (cross-term) of price $P$ with exogenous variable $\mathrm{Z}$, as follow:

$$
Q=\alpha_{0}+\alpha_{1} P+\alpha_{2} Z+\alpha_{3} P Z+\varepsilon
$$

Thus the exogenous variable $\mathrm{Z}$ does not only shift the demand curve but also rotates ${ }^{4}$ it. The price equation used is:

$$
P=\frac{-\lambda}{\alpha_{1}+\alpha_{3} Z} \cdot Q+\beta_{0}+\beta_{1} Q+\beta_{2} W+\eta
$$

By using Figure 1, the logic of this structural model can be described as follow. With the change of exogenous variable $\mathrm{Z}$, the slope degree of the demand curve and intercept will change. If the market behaves competitively, the rotation of the demand curve around the previous equilibrium will not change the equilibrium, so it is fixed in $\left(\mathrm{Q}_{1}, \mathrm{P}_{1}\right)$. However, if the firm has the market power, there will be a change in the equilibrium to be $\left(\mathrm{Q}_{2}, \mathrm{P}_{2}\right)$. Thus, the rotation of the demand curve caused by the exogenous variable $\mathrm{Z}$, gives a different response between competitive markets and monopoly markets.

3 The verification for this identification problem was conducted by Lau (1982) which he called it as impossibility theorem

4 It is necessary to estimate $\lambda$ because in the equation (8), variable $\lambda$ is related to variable $Q$, while variable $q$ consists of two, $q$ that is bound with $\alpha$ and $q$ that is bound with $\beta$. By this rotation, then $q$ can be separated from which is only bound with $\alpha$ and $\lambda$. 


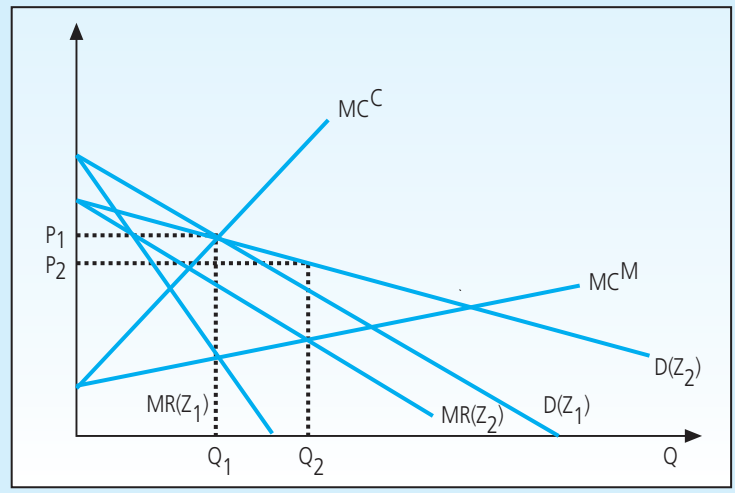

Picture 1. Response difference between competitive and monopoly markets

\section{METHODOLOGY}

Market power in this study uses a quantitative approach by conducting inferential testing to the empirical model that was developed. Basic modeling refers to a variety of empirical studies that apply the BL oligopoly model, such as Alexander (1988), Steen and Salvanes (1999), Toolsema (2002), Bikker and Haaf (2002), and Bikker (2003); the last three studies applied the BL oligopoly model in banking industry. Departing from these three models used to estimate market power in loan market, are two structural equations, the loan demand function and supply function (cost function).

Referring to the demand function format (9), then the loan demand function used is:

$$
\begin{aligned}
& K R E D I T=\alpha_{0}+\alpha_{1} S K M K+\alpha_{2} P D B+\alpha_{3} S K M K * P D B+\alpha_{4} S B I 3 \\
& +\alpha_{5} S K M K * S B I 3+\alpha_{6} C A B A N G+\alpha_{7} I N F L A S I+\alpha_{8} K R E D I T_{-1}+\varepsilon
\end{aligned}
$$

where CREDIT is the total loans distributed by commercial banks to the private sectors (claims on private sector). For price, we use the interest rates of the working capital loan (SKMK)5, whereas exogenous variables that affect the loan use Real GDP (GDP) with base year 1993, as an indicator of the public income, 3-months Certificates of Bank Indonesia (SBI3), the number of branch offices (BRANCH), the inflation rate (INFLATION) and the quantity of loan in the previous period (CREDIT-1).

5 Besides the interest rate of working capital loan, the interest rate of investment loan can be used, however, because the movement of the both variables run in the same direction, there is almost no difference between using the interest rate of working capital loan or investment loan. 
There are two interaction variables; the interaction between loan interest rate (SKMK) with GDP and the interaction between SKMK and SB136. These two variables are used to rotate the demand curve.

From the supply side, based on equation (10), then demand or cost function of loan can be specified by the following equation:

$$
S K M K=-\lambda \frac{K R E D I T}{\alpha_{1}+\alpha_{3} P D B+\alpha_{5} S B I 3}+\beta_{0}+\beta_{1} \text { KREDIT }+\beta_{2} S D 1+\beta_{3} I N F L A S I+v
$$

where the exogenous variables used as cost determinant indicators of banking loan distribution is a deposit rate for 1 month-term (SD1), and the inflation rate (INFLATION).

Both of the structural equations in loan markets above were estimated by using Two Stage Least Square method (2SLS). The object of the study is the loan market of commercial banks (aggregate). Period used in the estimation model is the first quarter of 1990 (Q1: 1990) until the fourth quarter of 2004 (Q4: 2004). After adjustment, a total of 59 observations were obtained.

It should be underlined that there was an important test to be conducted on both structural models, which is the separability test. Technically, this procedure tested whether the interaction of variables used in the model is valid or not.

There are two structural equations in the empirical model, which respectively have one interaction variable. To estimate the market power $\lambda$, then the necessary condition is that both demand functions of the credit market are non-separable, which means it is the expected null

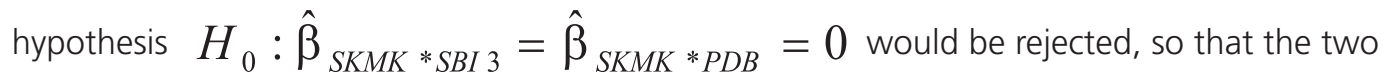
interaction variables, denoted as SKMK * SBI3 and SKMK * GDP, are still valid to use in the model.

\section{RESULTS AND ANALYSIS}

Loan demand model estimation results (11) using Two Stage Least Square (2SLS), is presented in Table 2. As previously stated, this market power estimation needs both equations to be non-separable. The result of the separability test conducted with Coefficient Test LRRedundant Test is given as follows:

6 Interaction with other exogenous variables, for instance branch offices and inflation did not give any significant result, so that they are not included in the model. 
Interest rate of market power
Redundant Variables: SKMKSBI3 SKMK*PDB
F-statistic
4. 073789
Probability
0.022959

Based on the above test, the null hypothesis is rejected at the $5 \%$ level of confidence. It can be concluded that loan demand function is non-separable at interest rates of 3-months Certificates of Bank Indonesia (SBI3) and income (GDP).

\begin{tabular}{l|r|r|}
\multicolumn{3}{c}{ Table 2: } \\
\multicolumn{1}{c|}{ Loan Demand Estimation Model } \\
& Coefficient & T-stat \\
Constanta & $-1.26 \mathrm{E}+15$ & -2.0204 \\
Interest Rate of working capital Ioan (SKMK) & $5.67 \mathrm{E}+13$ & 2.0444 \\
Real GDP (GDP) & 11.9359 & 2.0005 \\
3-months certificate of Bank Indonesia & $1.34 \mathrm{E}+13$ & 2.1306 \\
Loan (-1) & 1.1494 & 7.0338 \\
SKMK*SBI3 & $-5.44 \mathrm{E}+11$ & -2.3886 \\
SKMK*PDB & -0.5439 & -2.0687 \\
Branch Offices & $-2.04 \mathrm{E}+12$ & -1.7496 \\
Inflation & $8.94 \mathrm{E}+14$ & 2.9979 \\
\hline Adjusted R2 & 0.9344 & \\
DW Stat & 2.0124 & \\
F Stat & 105.873 & \\
Prob (F Stat) & 0.0000 & \\
Sources: author's calculations & & \\
Note: The dependent variable is the total loan value. Model Correction was conducted with White Heteroscedasticity &
\end{tabular}

For t-statistics test with null hypothesis $\mathrm{HO}: \beta=0$, it indicates that the value of t-statistics of all independent variables rejected the null hypothesis at the $5 \%$ level of confidence. In other words, all independent variables, the interest rate of working capital loan (SKMK), Real GDP (GDP), 3-months Certificates of Bank Indonesia (SBI), branch offices (BRANCH), inflation rate (INFLATION) and Credit lag variable ${ }_{(-1)}$, and the interaction variable (cross-term) between SKMK with GDP (SKMK * GDP) and SKMK with SBI3 (SKMK * SBI3), significantly (statistically significant) have a relationship with the dependent variable which is credit demand.

The influence of the interest rate of the working capital loan (SKMK) to the total loan value demand works in two ways; direct and indirect effects. The direct effect is shown by the 
SKMK coefficient by $5.67 \mathrm{E}+13$, which means each 1 percent increase of SMK would increase the number of SKMK loan demand by Rp. 56.7 trillion. The indirect effect is shown by two interaction variables, namely SKMK * SBI3 and SKMK * GDP. Both of interaction variables are negative, which are $-5.44+11$ and $-0.5439 \mathrm{E}$. The effect of total SKMK to the loan take into account the three coefficients, which amounted to $d K r e d i t / d S K M K=5.67 \mathrm{E}+13-5.44 \mathrm{E}+11$ * SBI3 -0.5439 * GDP.

It shows that the effect of SKMK on loan demand depends on 3-months Certificates of Bank Indonesia (SBI) and the Real GDP. By using the mean for SBI3 and Real GDP during the
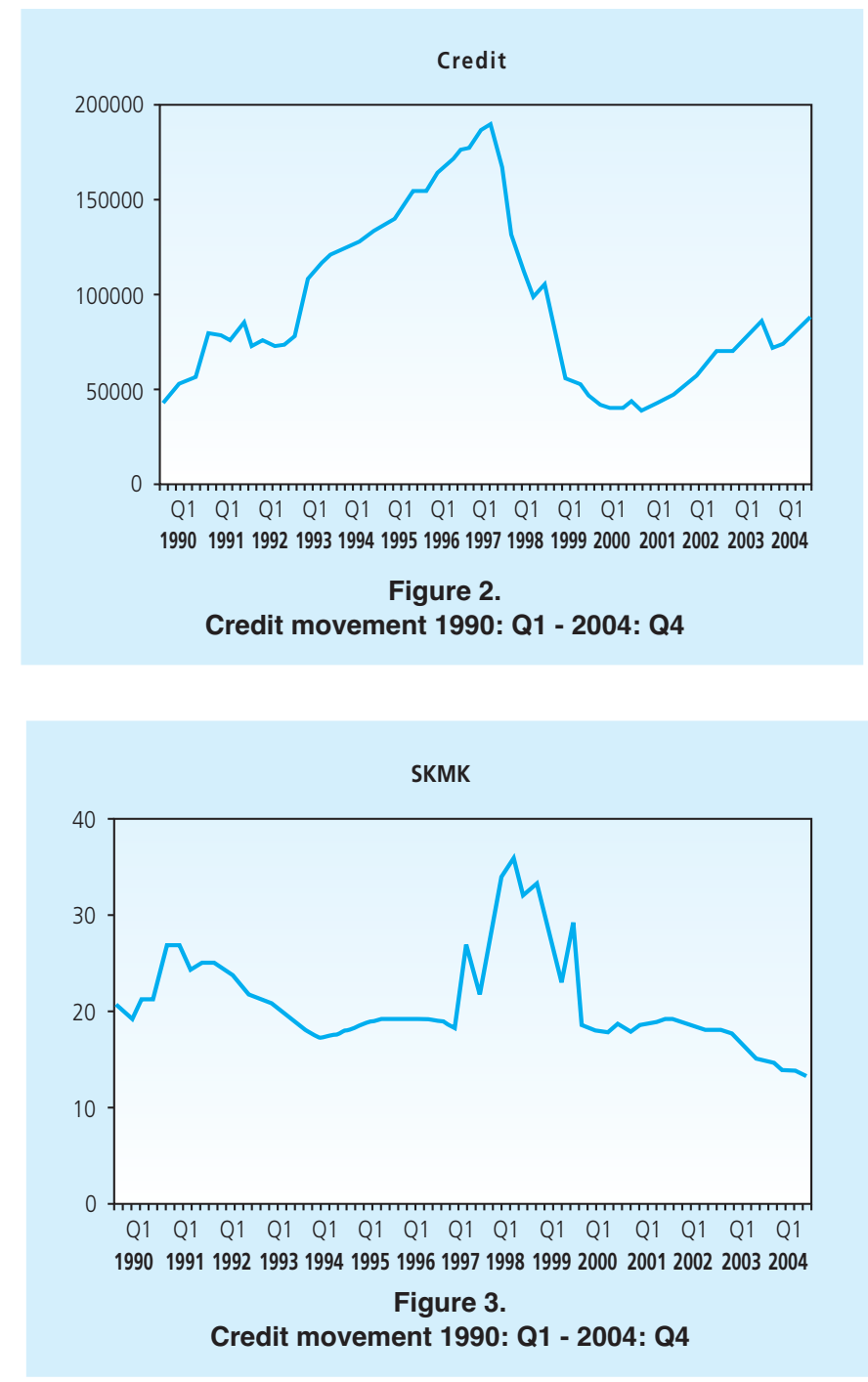

7 The average values of SKMK and GDP during the observation are 15.73 and 92,135.04, respectively. 
period of observation, we obtained that the SKM effect on the total loan demand was $4.81 \mathrm{E}$ +13 . SKMK positive effect on credit is not consistent to the hypothesis. In the following figure we can see the movement of both variables during the observation period.

From the two above figures, it can be seen that in some periods before the economic crisis (1991-1997) and after crisis (2002-2004), loan and SKMK variable moved in opposite direction, except in the crisis period where the total loan values experienced a sharp decline even though the interest rates of working capital loan had been lower. This one-directional movement patterns after the crisis, explained the positive impact of SKMK on credit.

The interest rate of working capital loan (SKMK) positively influenced the total loan value demand. The increase of 1 percent SKMK interest rate would increase the amount of loan by Rp 56.7 trillion. It contradicts the hypothesis because the relationship between loan interest rate and loan demand should theoretically be negative. The possible explanation of these results is that the parties who demanded loans from banks did not consider the loan interest rate as a constraint. It means despite the high loan interest rates, they will keep demanding for loan. In addition, another reason is the bank policy which is fairly easy in giving a loan, although the feasibility of the loan is not certain.

As the SKMK variable, the influence of public income indicated by GDP also has a direct and indirect effect. The direct effect of GDP to total the loan demand is 11.9359 , which means each 1 Rupiah rise in GDP will increase the loan demand by 11.9 Rupiahs. Meanwhile the indirect effect is shown by the coefficient of interaction variable by -0.5439 SKMK * GDP. The effect of the total GDP on credit is dKredit / dPDB $=11.9359-0.5439$ * SKMK. By using the average SKMK, then the total GDP impact on the loan was 3.38. This positive effect was consistent with the hypothesis that the amount of loan will increase along with economic development because of the need for investment and enterprises which will also increase.

Public income variable (GDP) positively affects the loan demand. Each increase of 1 Rupiah GDP will increase the loan by 11.9 Rupiah. It is consistent with the hypothesis that the more economy develops, the more loan demanded for investment.

The 3-months Certificates Interest Rate of Bank Indonesia (SBI) also positively affected the demand for loan, although the size effect of SBI3 also depends on the value of SKMK, as shown by the coefficient of interaction variable SKMK * SBI3. Although the interaction variable is negative, but overall, (dKredit/dSBI3 $=1.34 \mathrm{E}+13-5.44 \mathrm{E}+11$ * SKMK) SBI3 effect on the total loan value demanded remains positive by $1.97 \mathrm{E}+12$. The one-directional relationship between loan and SBI3 shows that the role of SBI3 as an instrument in encouraging the banking intermediary function does not work according to the hypothesis. When the SBI gets lowered, the Certificate of Bank Indonesia remains relatively less attractive than the banking products, then we expect collected third party funds to increase and ready to be injected into the economy.. However, what happened in the period of analysis is, when the SBI rate declines, the total loan value distributed decreased as well. In the following figure, the positive relationship was likely 
caused by conditions in the crisis period, where after its peak in the third quarter of 1998, SBI3 dramatically dropped, but the total loan value also remained low until 2001.

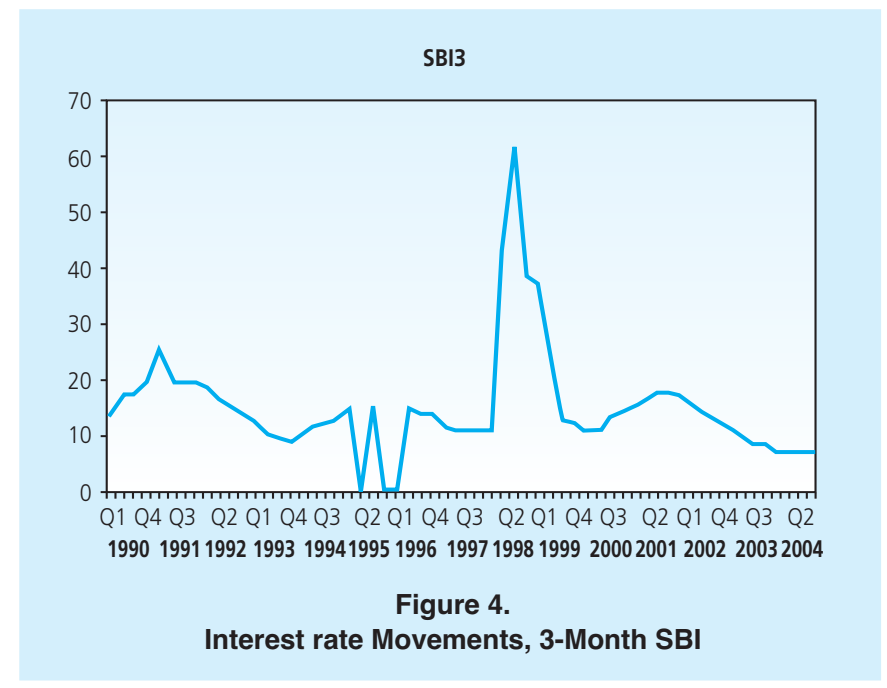

Interest rate variable of 3-months certificates of Bank Indonesia (SBI) also positively affected the demand for loans. An increase of 1 percent SBI3 will increase the loan by Rp 13.4 trillion.

The total loan value in the previous period also had a positive influence. This variable is essentially representing the speed of adjustment lag from one quarter to the next quarter. The total loan value in the previous period also positively influenced the current loan demand. Each 1 Rupiah increase in loan in the previous period will increase the demand for current loan by 1 , 15 Rupiahs.

Number of branch offices (BRANCH) has a negative correlation with the total loan value, where each increase of one unit of branch office will decline the total loan value by $\mathrm{Rp} 2.04$ trillion. This is contrary to the hypothesis that expressed the more number of branches, the greater the service coverage, would eventually increase the distribution of loan. At the beginning of observation, the number of branches was 2842, this value then increased significantly until the end of the analysis period by 7826. If it is associated with loan's movement as shown in Figure 2, then the negative relationship is, again, due to the movement over the crisis period.

Number of branch offices (BRANCH) has a negative correlation with the total loan value. It means branch offices will decline the total loan value by Rp 2.04 trillion. It is contrary to the hypothesis that expressed the more number of branches, the greater the service coverage, which eventually would increase the demand for loan.

Inflation rate (INFLATION) was positively related to the demand for loan. 1 point increase of inflation will increase the demand for loan by Rp 894 trillion. In the literature of banking and 
loan, the relationship between inflation and loan demand can be uni-direction or bi directional ${ }^{8}$. Explanation on this positive relationship is a firm using two funding resources to finance working capital, i.e. money (own capital) and capital loans (from banks). The high inflation rate penalizes the firm for using much more of its own capital; hence the loan from bank would be more desirable.

Inflation rate (INFLATION) was positively related to demand for loan. The increase of 1 point will increase the demand for a loan by Rp 894 trillion. Meanwhile, both interaction variables significantly influenced the demand for credit, but this will not be specifically analyzed because its function is to determine the market power level acquired by Bank Indonesia.

In Table 3, it is shown the results of estimation of the cost equation by using the interest rate variable of credit working capital loan (SKMK) as dependent variable. From first estimation result, the correlation test result of Ljung-Box test Q-statistics show that the estimation cost equation of the interest rates of working capital loan (SKMK) contained a serial correlation. By using ARIMA models in the first-order level to overcome the problem of serial correlation, and the White Heteroscedasticity-Consistent Covariance to overcome heteroscedasticity problem, then the equation of the cost of working capital loan interest rates (SKMK) after being fixed is as shown in Table 3.

\begin{tabular}{|c|c|c|}
\hline \multicolumn{3}{|c|}{$\begin{array}{l}\text { Table 3: } \\
\text { Estimation Results Loan Supply (from the cost side, after correction) }\end{array}$} \\
\hline Variable & Coefficient & T-stat \\
\hline Constanta & 15. 1608 & 11.9184 \\
\hline Loan & $-1.11 \mathrm{E}-14$ & -4.0635 \\
\hline Interest Rate of 1-month deposit (SD1) & 0.5501 & 8. 2691 \\
\hline Mark-up $(\lambda)$ & -0.0233 & -1.6961 \\
\hline Inflation & -40.3296 & -2.1643 \\
\hline $\operatorname{AR}(1)$ & 0.1336 & 0.1372 \\
\hline $\mathrm{MA}(1)$ & 0.1275 & 0.1279 \\
\hline Adjusted R2 & 0.6458 & \\
\hline DW Stat & 1.7179 & \\
\hline F Stat & 24. 3750 & \\
\hline Prob (F Stat) & 0.0000 & \\
\hline \multicolumn{3}{|c|}{$\begin{array}{l}\text { Sources: author's calculations } \\
\text { Description: This loan supply approached from the cost side, is represented with the interest rate of working capital loan (SKMK) as the } \\
\text { dependent variable. }\end{array}$} \\
\hline
\end{tabular}

For t-statistics test with the null hypothesis $\mathrm{HO}: \beta=0$, it indicated that the value of $\mathrm{t}$ statistics of all independent variables rejected the null hypothesis at $5 \%$ confidence level (except for mark-up variable at 10\% confidence level). In other words all independent

8 Refer to Amidu (2006), who explained some studies in terms of the relationship between inflation and demand for loan. 
variables, including loan, interest rate of 1-month deposits (SD1), inflation rate (INFLATION), even the variable that became the main object in this study mark-up variable $(\lambda)$, were significantly related to the dependent variable, which is the interest rates of the working capital loan (SKMK).

The total loan value negatively influenced the interest rate of SKMK. The increase of 1 trillion Rupiahs of loan will decrease SKMK by 1.11 percent. The negative relationship is contrary to the hypothesis where the total loan value should have increased then the cost of managing the loan would be increasing so that the bank would increase the interest rate of working capital loan (SKMK). The negative effect of the total loan value distributed to SKMK allegedly occurred because banks try to reduce the risk of non-performing loans. In the early period (1990), the ratio of non-performing loans was estimated at $4.5 \%$, but increased to $12 \%$ in 1994 , and the bank managed to reduce it to $8.8 \%$ in 1996 . However, the ratio increased again after the crisis. During the period after the crisis, the ratio was successfully decreased where in 2001 it was $12.13 \%$ and dropped down to 4.5\% in 2004 (December).

The total loan value negatively affected the interest rate of SKMK. The increase of 1 trillion Rupiahs of the amount of loan will decrease SKMK by 1.11 percent. It is contrary to the hypothesis expressed, which means the greater the amount of loan distributed, does not necessarily add to the cost of banking reflected through the interest rate of SKMK, but instead, banks would cut the interest rate to reduce the risk of non-performing loans.

1-month interest rate deposits (SD1) affected positively on the interest rate of working capital loan (SKMK). The increase of SD1 by 1 percent will increase SKMK by $0.55 \%$. This is consistent with the hypothesis that interest rates of SD1 acts as the main cost (cost of fund) of the distribution of credit. The larger banks pay interest on funds collected, and then it requires

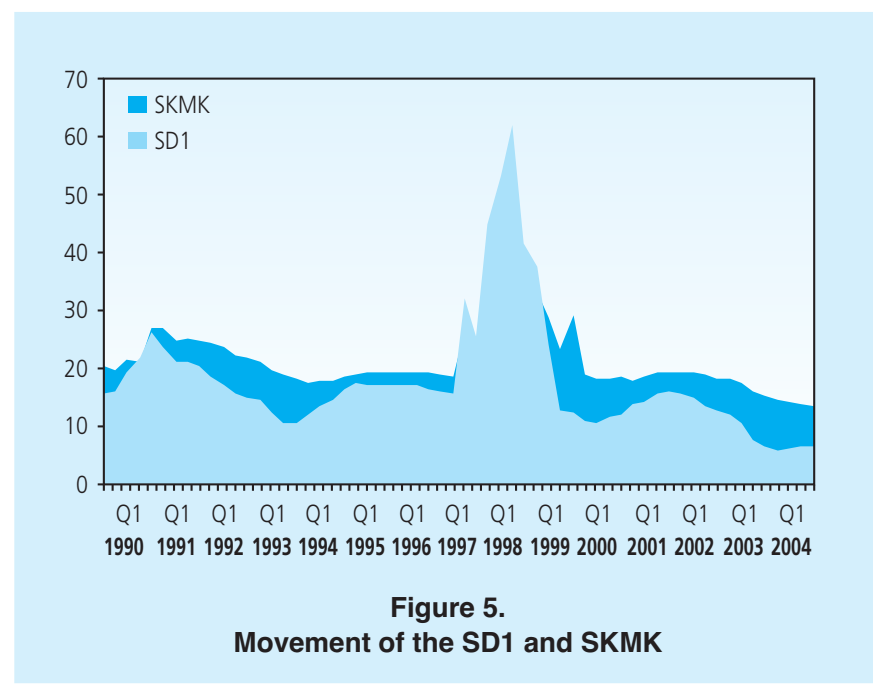


a larger income as well. That is why interest rates of SKMK would increase. This uni-directional relationship is shown in Figure 5, where the credit interest rate (SKMK) is always higher (except in the period of crisis) than the 1-month deposit interest rate, and has a uni-directional movement.

The variable of 1-month interest rate of deposits (SD1) influenced positively on the Interest Rate of working capital loan (SKMK). The increase by 1 percent on SD1 will increase SKMK by $0.55 \%$. This is consistent to the hypothesis that the SD1 interest rate serves as a major cost of loan distribution. The more banks pay the interest from the collected fund, and then they require a larger income as well. That is why SKMK interest rates would be increased.

Inflation rate (INFLATION) negatively influenced the interest rates of working capital loan (SKMK), in which each increase of 1 percent Inflation would decrease SKMK by 0.4 percent. This negative relationship is contrary to the hypothesis, whereby when the inflation rate rises, the cost of funds collected by banks would increase because the banks receive a repayment which is fewer than the funds distributed at the first time. To prevent it, the banks will increase the loan interest rate. However, in this paper, the relationship between inflation and loan interest rates would be negative.

A possible explanation of these results is the existing positive relationship between the risk of bad debts and the inflation rate. To reduce the risk of bad debts when inflation increases, the bank should lower the interest rate of the loan. As in the previous description, the ratio of bad debts was relatively high during the period of analysis and only decreased at the end of the period of analysis.

Inflation rate (INFLATION) negatively influenced the interest rate of working capital loan (SKMK). It means the increase of INFLATION rate by 1 percent will decrease the SKMK by 0.4 percent.

What became the main object of this study is the level of market power exercised by Indonesia's national banks. In constructing the main hypothesis of this study, the market power in the loan market of the Indonesian banking industry is expected to be high because it has a high level of concentration. In other words, it estimated that the level of competition in Indonesian banking industry is relatively low. From the result estimation of the above model, it obtained the level of market power (mark-up) by 0.023 . With the low level of market power, it proved that the joint hypotheses which expressed that the empowerment of market power in the banking loan market was high, which also shows that the relatively low level of competition cannot be accepted.

The estimation result of market power in the loan market of the Indonesian national banking industry generated quite a low mark-up value. The table below shows a comparison of the market power level between loan market of Indonesian banking and hypothetical oligopoly condition. 


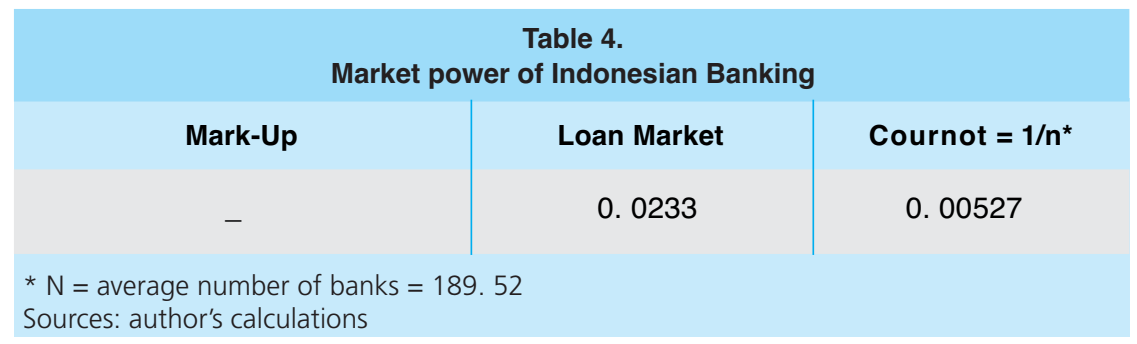

Table 4 shows that the mark-up value in the loan markets is 0.0233 . Based on Wald test, these values are also different significantly from zero (10\% confidence level).

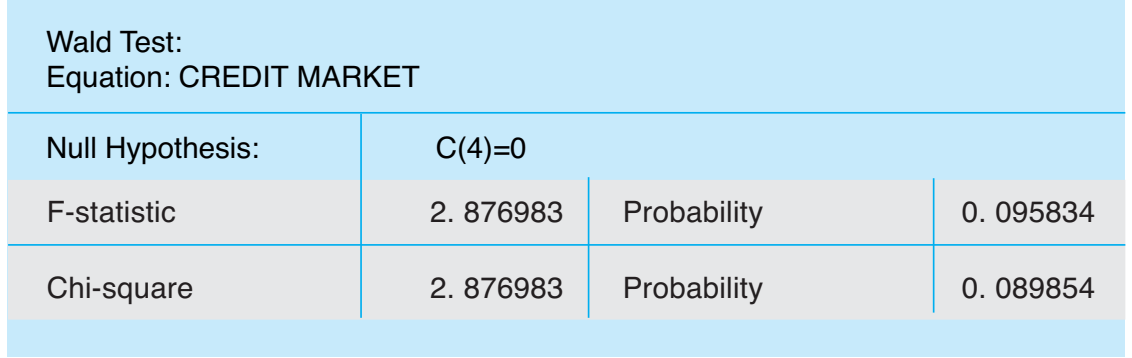

Thus market power in the loan market is not the same as the market power in perfectly competitive market, even when it is compared with the level of market power of Cournot competition by 0.00527 . However, since the mark-up value is far less than 1 (monopoly market power), then it can be inferred that the level of competition in it is also quite high.

From these results, it can be concluded that the use of (exercising) market power in the loan market of the Indonesian banking industry is still quite low, which means the level of competition in the loan market of the Indonesian banking industry is still quite high.

\section{CONCLUSION}

This paper is intended to test the joint hypotheses regarding the level of competition and market power of the loan market in Indonesian banking industry using the Bresnahan-Lau (BL) oligopoly model framework. Market powerindicates the ability of firms in the market to influence prices, and shows the level of competition in the market.

BL oligopoly model used in this paper is a structural model that describes the relationship between the demand and supply curve, within which the determination of market power does not need production cost data that is often difficult to access.

By using the model, the findings showed that the level of competition in the loan market of the Indonesian banking industry is still high as seen from the mark-up coefficient by 0.0223 . 
However, although the level of competition is high, the credit market of the Indonesian banking industry cannot be said to be a perfectly competitive market.

The study results using BL oligopoly model estimated that the competition level of the structural equations have different results when compared 'measuring' the level of competition based on the level of banking concentration. Based on the concentration level at the value of CR4 estimated by 40s, it shows that banking industry remains relatively competitive. However, with the BL oligopoly model, it is seen that the banking industry in the credit market has already been relatively competitive.

The study uses the BL oligopoly model that estimates market power directly from the structural equation, and implies that it is not valid to use market structural data as an indication of the level of competition in the loan market for the Indonesian banking industry. Even though the Indonesian banking industry in the loan market is structurally quite concentrated, the competitive behavior of commercial banks in distributing credits is quite high. 


\section{REFERENCES}

Alexander, D. L., 1988. The Oligopoly Solution Tested. Economic Letters 28, 361-364.

Amidu, Mohammed, 2006. The Link between Monetary Policy and Banks Lending Behavior:

The Ghanaian Case. Banks and Bank Systems. Vol.1, Issue 4.

Bikker, J., A., 2003. Testing for Imperfect Competition on EU Deposit and Loan Markets with

Bresnahan's Market power Model. De Netherlandsche Bank Research Series, Amsterdam.

Bikker, J. A. and K. Haaf, 2002.Competition, Concentration and Their Relationship: An Empirical

Analysis of the Banking Industry. Journal of Banking and Finance 26, 2191-2214.

Bresnahan, T. F. , 1982. The oligopoly Solution Concept is Identified. Economics Letters 10, 8792. . , 1989. Empirical Studies in Industries with Market power, In: Schmalensee, R.

Willig, R. D. (Eds.), Handbook of Industrial Economics, vol. 2. North-Holland, Amsterdam.

Church, J. , And R. Ware, 2000. Industrial Organization: A Strategic Approach. Boston, Massachusetts, Irwin McGraw-Hill.

Cole, David C. and Betty F. Slade, 1996. Building a Modern Financial System: The Indonesian Experience, Cambridge University Press.

Lau, L. J., 1982. On Identifying the Degree of Competitiveness from Industry Price and Output Data. Economics Letters 10, 93-99.

Layard P. R. G and Walters, A. A., 1978. Microeconomic Theory. Mac-Graw Hill.

Lubis, AndiF. , 1997. Structure and Market power: Analysis of Panel on Processing Industry from 1985 to 1994. S1 FEUI Thesis (unpublished). Depok.

Norman, G and La Manna, M (eds), 1992. The New Industrial Economics, Aldershot, Edward Elgar.

Panzar, J. and Rosse, J., 1987. Testing for 'Monopoly' Equilibrium, Journal of Industrial Economics 35, 443-456.

Steen, F. and Salvanes, K. G., 1999. Testing for Market power Using a Dynamic oligopoly models. International Journal of Industrial Organization 17, 147-177.

Toolsema, L. A., 2002. Competition in the Dutch Consumer Credit Market. Journal of Banking and Finance 26, 2215-2229. 